\title{
Making Academic Reference Services Work
}

\section{David W. Lewis}

\begin{abstract}
Recent discussion of reference service in academic libraries has considered alternative approaches to service and has called on academic reference librarians to play new roles. Absent from most of the discussion is an understanding that organizational changes are required if reference librarians are to accomplish what is being asked of them. Without these organizational changes these new roles and responsibilities will be impossible. To make reference service in academic libraries effective five changes are required: (1) reference librarians must be given clear budgetary and programmatic authority; (2) the hierarchy must be flattened and reference librarians placed closer to the top of the organization; (3) support services must be provided so that reference librarians are not encumbered by nonprofessional tasks; (4) reference librarians should be brought together and not isolated in small departments; and (5) public services planning and priority setting should be done by reference librarians.
\end{abstract}

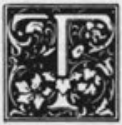

he number of articles discussing reference librarians and their roles and functions seems to have increased in the last several years. The topics range from new techniques and styles of reference to the confrontation with technology and staff burnout.' I believe this recent discussion is more than the usual navel gazing. Its urgency reflects an understanding that change is required, even if the problems being addressed are not yet clearly defined, and the answers are often platitudes. Such a response is not surprising considering the radical changes that have taken place in library and information technology over the past two decades. As Virginia MasseyBurzio states in explaining the justification for a major shift in approach to reference services at Brandeis University, "Since the mid-1970s, we had been adding more and more services like on- line searching and bibliographic instruction with little increase in staffing. The introduction of CD-ROM technology caused a bad situation to reach crisis proportions." ${ }^{2}$ The past twenty years have seen the introduction of online searching and OCLC, then OPACs and CD-ROMs. Now reference librarians have cheap access to full-text online databases, sameday document delivery, and the Internet. For many of us, the technological futures we imagined only a few years ago have already come and gone.

Missing from most of this discussion is an understanding that unless organizational structures in academic libraries change, the reference librarians who are being asked to change their behaviors and roles understandably will balk. In many cases, the roles reference librarians are asked to play are incompatible with the way their work lives and their organizations are structured. Too often

David W. Lewis is Head of Public Services at the University Libraries, Indiana University Purdue University, Indianapolis, 755 West Michigan Street, Indianapolis, Indiana 46202-5195. E-mail address: dlewis@indycms.iupui.edu 
reference librarians lack the incentives to cooperate, to change, and to excel. Sadly, the organizational structures of most academic libraries discourage professionalism. Academic libraries are bureaucratic and top heavy. They stifle initiative. After describing the overwhelming response to a request for proposals for the initial "Apple Library of Tomorrow" grants, Susan Martin comments, "If this response is an indication of thinking and planning, then the fault in the system [the failure to provide innovative services] does not lie with lack of imagination or creativity among librarians." ${ }^{\prime 3}$ It certainly does not. The fault lies with our organizations. What is remarkable is that so many talented and dedicated people battle against these odds to provide good service. In this article I will review the expectations that appropriately are being placed on reference librarians and will look at the organizational changes that are required if reference librarians are to meet these expectations.

\section{BACKGROUND}

The recent discussion of reference may be traced back to Thomas Surprenant and Claudia Perry-Holmes' $1985 R Q$ article "The Reference Librarian of the Future: A Scenario." 4 Unfortunately, but probably not surprisingly, like much of the subsequent literature the Surprenant and Perry-Holmes article contains more exhortations and generalities than concrete suggestions. Their concluding words, "What is most needed at this critical juncture for librarians is an acceptance of innovation, a willingness to experiment, self-confidence in our abilities and potential, and most of all, a conviction to lead," are typical. ${ }^{5}$ Jerry Campbell concludes his widely discussed article, "Shaking the Conceptual Foundations of Reference: APerspective," with a similarly sweeping challenge:

I have outlined this new role for what are now our reference colleagues because they are uniquely qualified and situated to assume the role.... Yet, it is a stronger role than they presently play. If they accept it, it will place upon them a large share of the burden for creating a viable twenty-first-century library. ${ }^{6}$

Jennifer Cargill's more recent "The Electronic Reference Desk: Reference Service in an Electronic World" continues in the same vein:

Underlying this is the need to know our clients, our constituencies, better. Similarly, we must organize our libraries for the user, not for the librarian. We must organize services to meet the actual information needs, habits, and preferences of patrons-not what librarians think is wanted. We must create the situation whereby librarians can provide the in-depth assistance and knowledge for which they are trained. ${ }^{7}$

Shelia Creth's "The Organization of Collection Development: A Shift in the Organization Paradigm" addresses similar issues. ${ }^{8}$ The authors of the last three articles are directors at ARL libraries, and as such their views may be seen as representing the contemporary administrative view of the role of reference librarians in academic libraries today.

Although each approaches the problem from a different perspective, all three authors stress the need for change. They all are looking for a different way to do reference - a way that is clientbased and effectively applies the new electronic tools to increase quality and productivity. Campbell asks that we find a new "economic model." Cargill suggests that we must "focus and personalize our reference services to meet the needs of our various constituencies more effectively." ${ }^{10}$ To do so she suggests that we must "redirect our energies from collection building and bibliographic control to concentration on information management and access." gests that collection development, because it combines concerns for both the user and the sources, "should provide the bridge or link to establish an integrative link in the research library." ${ }^{12}$

Perhaps the most intriguing speculation results from yet another perspective. Michel Bauwens proposes that reference librarians must become both organizationally and technologically 
networked. He says, "The proposed model of a strategic network of cybrarians is a way forward for integrating librarians into a network of experts. It requires from us a new attitude, centered on serving our clients, and an openness both to technology and to people, as expressed in the concept of networking." ${ }^{\prime 13}$ Unfortunately, Bauwens' proposals are vague and are focused on librarians in industrial and research settings, but his concept is challenging, and his new job title, cybrarian is certainly more pleasing than Campbell's access engineer. ${ }^{14}$

A common theme of the work cited above is that the new role of the reference librarian will be professionally exciting and empowering, but as Tom Peters says at the beginning of his latest book, Liberation Management, "I've come to realize that, in this madcap world, turned-on and theoretically empowered people... will never amount to a hill of beans in the vertically oriented, staff-driven, thick headquarters corporate structures that still do most of the world's business."15 Unfortunately, in the library world this truth has generally not been grasped. For instance, in concluding an article on managing emerging technologies, Susan Martin states: "Technological activities will not in themselves require reorganization in the immediate future. After all, thus far, only those applications are being discussed which are direct translations of functions which take place in a traditional structure."16 Sadly, academic libraries are in general as stifling as the business organizations that Peters studies. What is missing in the exhortations cited above is an understanding that unless the structure of academic libraries changes, the roles that reference librarians need to play will be impossible to achieve.

\section{ASSUMPTIONS AND EXPECTATIONS}

I will use the terms reference services and reference librarian in a broad sense. My concepts include traditional reference desk services, selection and liaison activities, and assume involvement in bibliographic instruction and the implementation of a broad range of electronic products. Other nomenclature may be more descriptive, but I see no need, at this point, to depart from terms which are widely understood in the profession and the academic community at large. I would rather enhance the meaning of librarian and have it take on new meaning than abandon the term.

In considering the roles and organizational structures that must evolve if reference services are to be successful over the next decade, I make the following assumptions:

- Reference librarians will need to balance a broad range of tasks-desk services, consultations, instruction, collection development, and involvement in implementing new technologies. ${ }^{17}$ This list of assignments reflects the need to maintain traditional desk and instructional services as well as to add consulting services and program and project development activities, especially with electronic products and services.

- Reference librarians will require a broad generalist's background to deal with a wide range of clients. At the same time subject expertise will become more important. It will be the basis for specialized reference work and liaison relationships with departments, schools, and faculties. Subject expertise and liaison with a client base will become the unifying thread of reference librarian's work. ${ }^{18}$

- There will be no significant influxes of new resources. Staffing levels will, at best, remain constant. Increased productivity will be expected and required.

- Library and information technologies will continue to change and evolve. This will require continued investment in equipment and a constant renewal of skills. These investments will, when wisely made, produce powerful and effective information tools. ${ }^{19}$

- Campus networks will expand and many significant information resources will be made available over these networks. These resources will be developed locally and purchased from vendors. They will be available on machines in the library, elsewhere 
on campus, and at other locations around the world. An important task for reference librarians will be integrating these resources and making them useful and convenient for client groups.

- Despite the presence of expanding networks, the level of use and demand for materials and services in the library building will continue at current levels, at minimum.

- Library users will be more diverse in the experience, expertise, and background.

\section{Reference librarians can be expected to be anxious and ambivalent when considering their future prospects.}

- There will be continued attempts to automate the reference desk function-Campbell calls for 75 percent of all questions to be answered through the use of technology-and to develop ways of using less highly trained staff. ${ }^{20,21}$ The desk function will be modified and supplemented, but the provision of assistance to users in the library will remain an important part of what reference librarians do. ${ }^{22}$

- The constant change in technologies will mean that demand for instruction in the use of the library's resources and services will continue to grow. Faculty expectations of the library will be outdated or unrealistic in many cases. Thus, meshing the library's capabilities with the curriculum will be a continuing challenge. ${ }^{23}$

The combined effect of these forces will be demanding, if not overwhelming, and while technology will offer some relief, achieving the possible benefits will require short-term investments of time, energy, and money that may prove difficult to generate.

In addition, there are easy to imagine and widely heralded futures in which the library and the librarian are absent, replaced with smiling machines and software agents. Reference librarians can be expected to be anxious and am- bivalent when considering their future prospects. In 1980 Brian Nielsen documented similar concerns in his article "Online Bibliographic Searching and the Deprofessionalization of Librarianship," so at least this situation is familiar. ${ }^{24}$ Despite legitimate preoccupations about the future and expanding demands, reference librarians will be more productive. Using new tools, they will be able quickly to provide library users with information that only a few years ago would have taken hours or even days to ferret out. They may feel fatigued, but will be satisfied professionally as they speculate about whether or not they have a future.

\section{EXISTING ORGANIZATIONAL STRUCTURES}

Too often, when librarians, especially library administrators, think about the organizational structures of libraries, they agree with Beverly Lynch:

Libraries are Bureaucracies. The bureaucratic elements which critics identify have their sources, not in the red tape or pettiness of officials, but in the attempt of the library to control its environment. The elements of bureaucracy emerge from its attempt to ensure its efficiency and its competency and from its attempt to minimize the impact of outside influences. Although variations will exist in the bureaucratic conditions, libraries will remain bureaucratic in form. ${ }^{25}$

In an article on conflict in academic libraries, William Pettas and Steven Gilliland cite arguments similar to Lynch's and laud the stability and continuity provided by bureaucracies: "The implication of bureaucratic efficiency, however, is not that there is a lack of conflict in reaching desired objectives; rather, the implication is that methods of resolving or lessening conflict are inherent in the bureaucratic structure. [Italics in the original.] ${ }^{\prime 26}$ In other words, the bureaucratic structures in libraries will work if they are used correctly.

While many have been slow to recognize the full implications, circumstances have changed and the advantages of bu- 
reaucratic structures are no longer so compelling. Lewis Perelman, in his critique of American education, states the case boldly:

The decontrol of knowledge therefore inevitably must drain the lifeblood from bureaucracy. Information technology that diffuses and disperses the creation and communication of knowledge assaults the genetic program, the very DNA of bureaucracy, in a way that is ultimately indefensible.... The more an organization or institution attempts to join the information revolution, the more the technology itself will break down the internal bureaucracy until the organization either becomes ungovernable, and breaks apart, or flips into a new, viable, but nonbureaucratic form of governance. ${ }^{27}$

\section{What has become increasingly clear is how deeply the prevailing hierarchical and bureaucratic structures are entrenched in academic libraries.}

If we believe our own propaganda, academic libraries are in the vanguard of the information revolution. As such, we should not expect to escape the organizational changes predicted by Perelman. Most academic libraries have automated their record structures and can now relax the tight controls necessary when standardized manual tasks were used to manage huge paper files. For many years the failure of bureaucratic structures to integrate and coordinate across functions has led to task forces and committees in such numbers that committee participation is a significant part of most academic librarians' jobs. This is an overhead academic libraries can no longer afford.

To date, there have been some small modifications in the established ways academic libraries do business, but despite calls for more radical approaches, such as the use of matrix organizations, parallel structures, quality circles, or teams, little has changed. ${ }^{28,29}$ Most academic libraries remain hierarchical and bureaucratic, discretion and authority are closely held by administrators, and front-line librarians mix high-level professional work with routine tasks. Unfortunately, as Charles Martell points out, "In libraries, the desire to protect power and control within the organization may lead some major stakeholders to ignore or minimize the needs of external constituencies. ${ }^{130} \mathrm{He}$ goes on, "Changes in the design of academic libraries are probably necessary if significant improvements are to occur in the organizational/environmental fit. These changes would quite naturally include the organizational structure." ${ }^{\prime 31}$

\section{ALTERNATIVE STRUCTURES}

In response to the bureaucratic reality, the concept of a client-centered academic library was developed some years ago. ${ }^{32}$ The most lucid expression of this model is Martell's Client-Centered Academic Library. ${ }^{33}$ He proposed teams of three to five librarians with several support staff, and suggested that these groups would provide advanced reference, collection development, instruction, and original cataloging in a specific area or discipline. Martell's organizational chart shows these groups reporting through a governing council to the library director. ${ }^{34}$ As Martell notes, his proposals are organizationally similar to those made by Booz, Allen \& Hamilton, Inc. for the Columbia University Library in the early 1970 s. ${ }^{35}$ This model was not generally applied for several good reasons. First, the overwhelming day-to-day demands of undergraduate students in the library and at the reference desk were difficult to reconcile with the less numerous, but more sophisticated and politically significant, demands of faculty. The client-centered model's implicit assumption-which I believe to be incorrect-was that the level of the individual making a query and the skills required to respond to it were directly related. Expert librarians would address the needs of faculty and advanced researchers and less skilled 
staff would deal with freshmen. Secondly, it generally has not been possible to coordinate the subject specific tasks in technical and public services, probably because the functional skills required to do advanced reference and to do original cataloging have both been changing rapidly.

Some years ago I suggested an organizational paradigm for academic libraries. $^{36}$ At that time I suggested that academic libraries should become professional bureaucracies. A professional bureaucracy, as I described it:

relies for coordination on the standardization and high level skills of its operators [librarians], and many decisions, both operational and strategic, are made by these operators. Professional bureaucracies tend to be decentralized and democratic for the professionals in the operating core. Because of this decentralization there is a small middle line and large spans of control. The technostructure is also small because many of its tasks are performed by the professional operators. The support staff, on the other hand, tends to be large in order to give the professionals as much aid as possible. The strategic apex often does not so much supervise the operating core as provide a link to the broader environment. ${ }^{37}$

The central issue, as I saw it then, was to create an organization that could balance the autonomy and discretion required to innovate and the coordination and commonality of purpose required to focus this innovation on a shared goal. The theory laid out in this article seems to remain sound. What has become increasingly clear is how deeply the prevailing hierarchical and bureaucratic structures are entrenched in academic libraries. Despite well-intentioned calls, like those cited above, for changes in the roles of reference librarians, I am firmly convinced that no fundamental change will come about until we transform the organizational structure of academic libraries. Lynch identifies the need for libraries to coordinate and to control tasks to ensure efficiency and competency. What we neglect when we heed this call is the stifling effect of the controlling and coordinating mechanisms on our service goals.

Service organizations must be reactive and responsive to their clients. For libraries to become effective service organizations they should create a climate in which professionalism, especially among reference librarians, can flourish. If reference librarians are going to innovate and apply technology effectively, if they are going to restructure the library so that it meets its clients needs, and if they are going to be the library's representatives to significant portions of the academic community, then they must occupy a new place in the library's organizational structure. Academic libraries must move away from a concern for control and must place a strong emphasis on the need to allow truly professional practice and innovation. When in doubt, reference librarians should be set free to do what they think must be done. The organizational structures of most libraries are not effective in today's environment. In the environment they will face tomorrow, they will fail completely.

\section{WHAT MUST HAPPEN}

An effective academic library should look like a law firm or an advertising agency. It should become a professional bureaucracy. Peters paints a picture of the effective organization as a lean, flexible, client-based, team-centered organization responsive both to its customers and to changes in technology. These organizations, Peters argues, must get close to markets and be small enough to shift focus quickly. He discusses the "four ephemerals"-"ephemeral 'organizations' ... joined in ephemeral combinations... producing ephemeral products . . . for ephemeral markets ... FAST." 38 Does this sound like your library? These are our circumstances. They require a focus on serving users and on quickly developing user-based services and programs, and then changing them when the sources or the client groups change. If academic libraries are to become client-centered, they must de- 
velop a variety of services and ways of delivering them. There are, after all, many clients, and the whole point of focusing their needs is to provide services to them in a way they find useful and convenient. We need to change our way of thinking. Rather than trying to find the one way of doing business that serves most people well, we need to provide mechanisms that allow us to develop many different ways to serve many niche groups.

Reference librarians can and should do this work and as such are quickly becoming the library's most valuable resource. This central truth needs to be recognized. To maximize the effectiveness of reference librarians, five things must happen:

1. Reference librarians must be given clear budgetary and programmatic authority.

2. The hierarchy must be flattened and reference librarians placed closer to the top of the organization.

3. Support services must be provided so that reference librarians are not encumbered by nonprofessional tasks.

4. Reference librarians should be brought together and not isolated in small departments.

5. Public services planning and priority setting should be done by reference librarians.

\section{Give Reference Librarians Authority}

Reference librarians need to become the library's customer service representatives and product developers. To play this role they will need to have authority and autonomy. This is the key issue: authority does not mean consultation; authority means the ability to make decisions.

There are two important authorities. The first is the authority to speak for the library. Reference librarians must be able to commit to the development or modification of programs to meet the specific needs of a client group. To do this, reference librarians need to be knowledgeable about the library's affairs. They need to be kept fully aware of budget and policy decisions.

A second authority is also essentialthe authority to spend money. While the authority to select books is common, this is the limit of financial discretion that is allowed most reference librarians. In many cases, especially in response to escalating prices and budget constraints, even journal subscription decisions are made at a higher level. Equipment and software are generally requested by department heads and allocated annually by senior administrators. Coordination, continuity, and budget control, especially in these times of declining resources, are used to justify these practices. These values are no longer the most important. More important is the need to match an ever-changing client group to an ever changing set of information services and products. A centrally administered budget with tightly held fiscal discretion is not capable of this. This approach creates disincentives and encourages behaviors that make doing more with less impossible. Individual librarians and departments need to be given budget allocations, and they need to be able to spend the money as they see fit. Only at this level is it possible to determine what is actually needed and what can be eliminated. This does not imply that there would be no accountability; rather, it means that both discretion and accountability should be passed down.

\section{Flatten the Hierarchy}

The need to flatten the hierarchy in academic libraries goes beyond the commonly cited issue of communication. Pettas and Gilliland state the usual argument, "The multiple layers of management within a large library may hinder communication of organizational objectives and the intent of policies and procedures." ${ }^{\prime 39}$ But after explaining that most libraries are relatively small organizations that have hierarchies comparable to much larger organizations, they go on to justify the hierarchy by suggesting that the coordination will be difficult and that managers will experience greater demands and stress if their 
span of control is too large. ${ }^{40}$ Though common, this view is mistaken.

Flattening the hierarchy is essential if reference librarians are to be effective. Regardless of how much responsibility has been assigned theoretically, if a reference librarian reports to someone who reports to someone who reports to the director, that librarian cannot make important decisions. ${ }^{41}$ That librarian cannot authoritatively represent the library to faculty who have an open door to the director three levels up in the organization. In this situation faculty, who know where the power lies, will take their concerns to a higher level and leave the reference librarian to deal with trivial concerns.

Whatever support services the library director enjoys should be available to all reference librarians.

It is my view that reference librarians should have no more than one manager between them and the library director. This should be possible in even large ARL libraries. This manager should serve as a managing partner rather than as a supervisor, and as such should be concerned with managing decision-making processes and communication, coordinating resource allocations, and coordinating of support services. Management of major reference programs such as instruction and desk services should be shared or rotated. Task teams should be used to establish new programs or services. Spans of control should be six to ten people.

\section{Provide Support Services}

There is a simple test. Whatever support services the library director enjoys should be available to all reference librarians. They should have full secretarial support, their telephones should be answered, their mail screened, and routine correspondence and reports should be handled by support staff. In addition, special services, such as desk top publishing, should be available and there should be support for maintaining and developing technologies.
I suspect that there is little theoretical disagreement with this position; rather, financial constraints will be cited as an excuse for not providing these levels of support. What should be understood is that reference departments are better off, if there is no other choice, trading a reference librarian for an administrative assistant. Seven reference librarians and an administrative assistant will be more productive than eight reference librarians who do their own clerical work.

A related issue is training. Reference librarians will need new skills, and libraries should expect to provide incentives and support for training. This will be different from the usual professional development support that consists of attending conferences and one-day workshops. Something more substantial is required. Libraries should provide support for courses and degrees. The aim must be the acquisition of new technical proficiencies. This will require additional continued investment in human resources.

\section{Bring Reference Librarians Together}

Bringing reference librarians together physically may seem at odds with the notion of putting them in touch with their clients who are spread out all over campus, but this is not so. ${ }^{42}$ Bringing reference staff together provides several benefits. First, the provision of support services is easier and more efficient if staff are clustered together. Second, proximity provides for the informal interactions that lead to a common sense of purpose and make working cooperatively easier. Finally, by creating large departments, the organization is flattened.

The consolidation of service points into larger operations makes it possible to use staff more efficiently. As noted above, there is and will continue to be a tension between the need to meet the day-to-day demands of large numbers of undergraduates and the need to develop and implement new sophisticated services. A tension between the general and process skill required to deal with beginning students and the subject expertise required to assist faculty and re- 
searchers will remain. The resources needed to provide high-level, sophisticated, and individualized assistance to everyone who walks in the door do not exist. Bringing reference staff together and consolidating service points makes it easier to mix staff and to maximize the effectiveness of available resources. The easiest consolidation is to integrate information desks and documents service points with general reference desks. Special or subject services points, especially inside a central building, should be eliminated.

\section{Planning}

While the need to develop and maintain the professional discretion of reference librarians should remain paramount, there is a legitimate concern that unbridled and uncoordinated professional discretion will lead to chaos and people working at cross-purposes. To assure that the authority reference librarians should have is channelled toward a common goal will require a formal and serious planning process. This process ought to decide issues such as the balance between desk services and instruction or consultation services. It should formulate strategies for pursuing all aspects of the library's public services program. It should decide what the electronic product mix will be for the coming yearwhich new services will be developed and which will be dropped. In my experience, this is a several-day process requiring the active participation of all of the reference librarians. It also requires preparation and follow-through. It is a time-consuming but essential activity.

The important difference between what needs to happen and most library planning is that the decisions taken will be implemented and substantial resources, both dollars and staff, will be put on the table. The result must be implementable plans, not recommendations to the library's administration. If such planning is to be effective, all reference librarians will need to develop analytic and group process skills. Over time an effective planning process should encourage a sense of common purpose and trust between individual professionals. When this happens, the library will begin to become an effective organization.

\section{IMPLEMENTATION}

As libraries adapt to the revolution in information technology and develop organizational structures to take advantage of these changes, reference services will become the primary function of the academic library, and reference librarians, if they are effective, will become the libraries' most valuable resource, more valuable even than the collection. This is a revolutionary change. The library will become an institution centered on its human resources.

To assure that the authority reference librarians should have is channelled toward a common goal will require a formal and serious planning process.

This revolution will require a radical departure from the generally accepted view that public and technical services are equally important and should receive roughly equal levels of support. I suggest that this apparently balanced view will lead to a misallocation of resources. Library administrators should be doing everything in their power to push the inevitable trend of streamlining and outsourcing technical services operations. It is clear that large external organizations can be significantly more efficient than most libraries in providing technical services. It is useful to compare the average cost of cataloging, easily in excess of $\$ 30$ per title in most libraries, with costs available from outside vendors such as OCLC. ${ }^{43}$ Funds saved by streamlining technical services should be put into reference staff and the support they need to operate effectively.

It also will be critical for reference librarians to accept the challenge that this model presents. If they are comfortable waiting behind a desk for the world to come to them, if they are not willing to change their ways of working so that 
they become more productive, then they will deserve their fate. Reference librarians will need to develop new roles because the functional skills that might have given them professional status a few years ago, such as online searching skills, are now taught to junior high school students. Reference librarians need to see themselves as technology transfer agents, as the catalysts of the information revolution. They sit at the locus between students and faculty and the rapidly changing information technology. It is a unique position that combines a knowledge of what is possible and what is required.

This is not a role for the comfortable and the contented. Those reference librarians who do not accept the challenge will be left behind. A decade ago Brian Nielsen considered the conflict between the reference librarian as teacher and the reference librarian as intermediary. $\mathrm{He}$ suggested that neither model was adequate and urged that reference librarians move away from the classic professional model that places users in a dependency relationship. ${ }^{44}$ A key assumption of the above analysis is that creating client-based services requires reference librarians to do as Nielsen asked. The current information technology allows, and even encourages, individuals to use the tools without intermediaries. What is required is someone to shape the tools to the particular needs of user groups. I believe reference librarians have an opportunity to achieve the new role Nielsen envisioned. But they can do so only if academic libraries are structured appropriately. Without organizational changes exhortations, no matter how challenging, will have little effect.

\section{REFERENCES AND NOTES}

1. The most interesting discussions of techniques and styles of reference are found in a series of Journal of Academic Librarianship symposiums. See "Reference Encounters of a Different Kind: ASymposium," Journal of Academic Librarianship 18 (Nov. 1992): 276-86; "Do Library Patrons Know What's Good for Them?: A Symposium," Journal of Academic Librarianship 16 (May 1990): 76-85, or "Replacing the Fast Fact Drop-In with Gourmet Information Service: A Symposium," Journal of Academic Librarianship 11 (May 1985): 68-78. Also see Rethinking Reference in Academic Libraries: The Proceedings and Process of Library Solutions Institute No. 2, ed. Anne Grodzins Lipow, Berkeley, Calif.: Library Solutions Press, 1993, and Adeane Bregman and Barbara Mento, "Reference Roving at Boston College," CERL News 53 (Nov. 1992): 634-37. For discussions of the impact of technology, see Jerry D. Campbell, "Shaking the Conceptual Foundations of Reference: A Perspective," RSR Reference Services Review 20 (Winter 1992): 29-36; Jennifer Cargill, "The Electronic Reference Desk: Reference Service in an Electronic World," Library Administration \& Management6 (Spring 1992): 82-85; Charles R. Hixson III, "CD-ROM and the Undergraduate: Reference and Instruction at Risk," RSR Reference Services Review 21 (Fall 1993): 31-34, 42, or Ilene F. Rockman, ed., "Reference Librarian of the Future: A Symposium," RSR Reference Services Review 19 (Spring 1991): 71-80/Recent discussions of burnout include Karen A. Becker, "The Characteristics of Bibliographic Instruction in Relation to the Causes and Symptoms of Burnout," RQ 32 (Spring 1993): 346-57; Ron Blazek and Darlene Ann Parrish, "Burnout and Public Services: The Periodical Literature of Librarianship in the Eighties," $R Q 31$ (Fall 1992): 48-59, or John Kupersmith, "Technostress and the Reference Librarian," RSR Reference Services Review 20 (Summer 1992): 7-14, 50.

2. Virginia Massey-Burzio, "Reference Encounters of a Different Kind: A Symposium," Journal of Academic Librarianship 18 (Nov. 1992): 276.

3. Susan K. Martin, "Information Technology and Libraries: Toward the Year 2000," College \& Research Libraries 50 (July 1989): 400.

4. Thomas T. Surprenant and Claudia Perry-Holmes, "The Reference Librarian of the Future: A Scenario," RQ 25 (Winter 1985): 234-38.

5. Ibid., 238.

6. Campbell, "Shaking the Conceptual Foundations of Reference: A Perspective," 35.

7. Cargill, "The Electronic Reference Desk: Reference Service in an Electronic World," 82. 
8. Shelia D. Creth, "The Organization of Collection Development: A Shift in the Organization Paradigm," Journal of Library Administration 14 (1991): 67-85.

9. Campbell, "Shaking the Conceptual Foundations of Reference: A Perspective," 33.

10. Cargill, "The Electronic Reference Desk: Reference Service in an Electronic World," 85.

11. Ibid.

12. Creth, "The Organization of Collection Development: A Shift in the Organization Paradigm," 77.

13. Michel Bauwens, "The Emergence of the 'Cybrarian': A New Organizational Model for Corporate Libraries," Business Information Review 9 (Apr. 1993): 67.

14. Campbell, "Shaking the Conceptual Foundations of Reference: A Perspective," 32.

15. Tom Peters, Liberation Management: Necessary Disorganization for the Nanosecond Nineties (New York: Alfred A. Knopf, 1992), 13.

16. Susan K. Martin, "Library Management and Emerging Technology: The Immovable Force and the Irresistible Object," Library Trends 37 (Winter 1989): 382.

17. The combination of reference and collection development responsibilities while not universal, is the generally accepted practice and can be expected to continue. See Creth, "The Organization of Collection Development: A Shift in the Organization Paradigm" or David G. Null, "Robbing Peter... Balancing Collection Development and Reference Responsibilities," College \& Research Libraries 49 (Sept. 1988): 448-52.

18. An interesting example of the possibilities is provided in Lori Arp and Gerald (Jay) Schafer, "Connecting Bibliographic Instruction and Collection Development: A Management Plan," RQ 81 (Spring 1992): 398-406.

19. This is clearly the case for OPACs; see David W. Lewis, "Research on the Use of Online Catalogs and Its Implications for Library Practice," Journal of Academic Librarianship 13 (July 1987): 152-57. It is also true of general periodical indexes on CD-ROM; see Douglas J. Ernest and Holley R. Lange, "INFOTRAC and WILSONDISC: A Comparison of New Technologies," RSR Reference Services Review 17 (Summer 1989): 67-75, or Lawrence E. Compton "A Study of the Use of CD-ROM Systems and Print Indexes at the University of Georgia Main Library," ERIC Document ED333892, 1991. An example of a further possibility is the Gateway project at Ohio State University; see Fred Roecker, "The Gateway: User Education in a Changing Environment," Research Strategies 10 (Summer 1992): 111-14, or Philip J. Smith and Virginia Tiefel, "The Information Gateway: Designing a Front-End Interface to Enhance Library Instruction," RSR Reference Services Review 20 (Winter 1992): 37-48.

20. Campbell, "Shaking the Conceptual Foundations of Reference: A Perspective," 32.

21. See, for example, Massey-Burzio, "Reference Encounters of a Different Kind: A Symposium," or Beth S. Woodward, "The Effectiveness of an Information Desk Staffed by Graduate Students and Nonprofessionals," College \& Research Libraries 50 (July 1989): 455-67. While the successful use of nonprofessional staff at reference desks has been reported, so have failures; see John O. Christensen and others, "An Evaluation of Reference Desk Service," College \& Research Libraries 50 (July 1989): 468-83.

22. Despite the Brandeis experiment described by Massey-Burzio, "Reference Encounters of a Different Kind: ASymposium," and calls like those from Barbara Ford, "Reference beyond (and without) the Reference Desk," College \& Research Libraries 47 (Sept. 1986): 491-94, I contend that a reference desk will remain in most academic libraries for some time to come. The problems with the typical reference environment documented by Joan C. Durrance, "Reference Success: Does the 55 Percent Rule Tell the Whole Story?" Library Journal 114 (Apr. 15, 1989): 31-36 does, however, indicate the need for modification of today's typical reference environment.

23. See, for example, Caroline Blumenthal, Mary Jo Howard, and William R. Kinyon, "The Impact of CD-ROM Technology on a Bibliographic Instruction Program," College \& Research Libraries 54 (Jan. 1993): 11-16; Stephen K. Stone, "Research and Information Retrieval among Academic Researchers: Implications for Library Instruction," Library Trends 39 (Winter 1991): 238-58, or Emily L. Werrell and Threasa L. Wesley, "Promoting Information Literacy through a Faculty Workshop," Research Strategies 8 (Fall 1990): 172-80.

24. Brian Nielsen, "Online Searching and the Deprofessionalization of Librarianship," Online Review 4 (Sept. 1980): 215-24.

25. Beverly P. Lynch, "Libraries as Bureaucracies," Library Trends 27 (Winter 1979): 267. 
26. William Pettas and Steven L. Gilliland, "Conflict in the Large Academic Library: Friend or Foe?" Journal of Academic Librarianship 18 (Mar. 1992): 27.

27. Lewis J. Perelman, School's Out: Hyperlearning, the New Technology, and the End of Education (New York: Morrow, 1992), 118.

28. See, for example, Peggy Johnson, "Matrix Management: An Organizational Alternative for Libraries," Journal of Academic Librarianship 16 (Sept. 1990): 222-29; William Fisher and Beth L. Brin, "Parallel Organization: A Structure Change Theory," Journal of Library Administration 14 (1991): 51-66; Charles Martell and John Tyson, "QWL Strategies: Quality Circles," Journal of Academic Librarianship 9 (Nov. 1983): 285-87; Joan S. Segal and Tamiye Trejo-Meehan "Quality Circles: Some Theory and Two Experiences," Library Administration \& Management 4 (Winter 1989): 16-19; Katherine W. Hawkins, "Implementing Team Management in the Modern Library," Library Administration \& Management 4 (Winter 1989): 11-15, or Gerald R. Lowell and Maureen Sullivan, "Self-Management in Technical Services: The Yale Experience," Library Administration \& Management 4 (Winter 1989): 20-23.

29. See Barbara B. Moran, "The Unintended Revolution in Academic Libraries 1939 to 1989 and Beyond," College \& Research Libraries 50 (Jan. 1989): 25-41, especially the sections on "Organizational Patterns" and "Staff," for a good review of the history and current state of academic libraries.

30. Charles Martell, "The Nature of Authority and Employee Participation in the Management of Academic Libraries," College \& Research Libraries 48 (Mar. 1987): 110-22.

31. Ibid., 112.

32. See Gardner Hanks and C. James Schmidt, "An Alternative Model of a Profession for Librarians," College \& Research Libraries 36 (May 1975): 175-87. Hanks and Schmidt's primary focus is professional rather than organizational, but they lay important groundwork.

33. Charles R. Martell, Jr., The Client-Centered Academic Library: An Organizational Model, (Westport, Conn.: Greenwood, 1983).

34. Ibid., 74.

35. Organization and Staffing of the Libraries of Columbia University: A Case Study, prepared by Booz, Allen \& Hamilton, Inc., (Westport, Conn.: Redgrave Information Resources Corp., 1973). Martell's client-centered groups have the same responsibilities as those of the Resources Group proposed by Booz, Allen \& Hamilton.

36. David W. Lewis, "An Organizational Paradigm for Effective Academic Libraries," College \& Research Libraries 47 (July 1986): 337-53.

37. Ibid., 339. The theoretical structure underlying this argument comes from Henry Mintzbergsee Henry Mintzberg, The Structure of Organizations, (Englewood Cliffs, N.J.: Prentice-Hall, 1979).

38. Peters, Liberation Management, 18.

39. Pettas and Gilliland, "Conflict in the Large Academic Library: Friend or Foe?" 27.

40. Ibid., 28.

41. When stated this way it may seen odd, but this is the usual circumstance for academic reference librarians. See the organizational charts in Organizational Charts in ARL Libraries: SPEC Kit 170 (Washington, D.C.: Office of Management Studies, Association of Research Libraries, January 1991). Nearly thirty ARL libraries supplied their organizational charts and in almost all cases there were at least two managers between the typical reference librarian and the library director, in some cases there were three layers.

42. Patricia Suozzi and Sandra Kerbel argue this point and contend that branch libraries should be considered as models rather than as "misfits." See Partricia A. Suozzi and Sandra S. Kerbel, "The Organizational Misfits," College \& Research Libraries 53 (Nov. 1992): 513-22. An interesting example of the centralize/decentralize arguments can be found in "Centralization or Decentralization of Library Collections: A Symposium," Journal of Academic Librarianship 9 (Sept. 1983): 196-202.

43. See George Harris, "Historic Cataloging Costs, Issues, and Trends," Library Quarterly 59 (Jan. 1989): 1-21 or Dilys E. Morris, "Staff Time and Costs for Cataloging," Library Resources \& Technical Services 36 (Jan. 1992): 79-95.

44. Brian Nielsen, "Teacher or Intermediary: Alternative Professional Models in the Information Age," College \& Research Libraries 43 (May 1982): 188. 